\title{
Developmental toxicity of PAH mixtures in fish early life stages. Part I: adverse effects in rainbow trout
}

\author{
Florane Le Bihanic ${ }^{1}$, Bénédicte Morin ${ }^{1}$, Xavier Cousin $^{2,3}{ }^{3}$, Karyn Le Menach ${ }^{1}$, Hélène Budzinski ${ }^{1}$, \\ Jérôme Cachot ${ }^{1,}$
}

\author{
${ }^{1}$ University of Bordeaux, EPOC, UMR CNRS 5805, 351 cours de la liberation, 33405, Talence Cedex, France \\ 2 IFREMER, Ecotoxicology laboratory, Place Gaby Coll, BP7, 17137, L'Houmeau, France \\ 3 INRA LPGP, Campus de Beaulieu, 35042, Rennes, France \\ *: Corresponding author : Jérôme Cachot, email address : j.cachot@epoc.u-bordeaux1.fr
}

\begin{abstract}
:
A new gravel-contact assay using rainbow trout, Oncorhynchus mykiss, embryos was developed to assess the toxicity of polycyclic aromatic hydrocarbons (PAHs) and other hydrophobic compounds. Environmentally realistic exposure conditions were mimicked with a direct exposure of eyed rainbow trout embryos incubated onto chemical-spiked gravels until hatching at $10{ }^{\circ} \mathrm{C}$. Several endpoints were recorded including survival, hatching delay, hatching success, biometry, developmental abnormalities, and DNA damage (comet and micronucleus assays). This bioassay was firstly tested with two model PAHs, fluoranthene and benzo[a]pyrene. Then, the method was applied to compare the toxicity of three $\mathrm{PAH}$ complex mixtures characterized by different $\mathrm{PAH}$ compositions: a pyrolytic extract from a PAH-contaminated sediment (Seine estuary, France) and two petrogenic extracts from Arabian Light and Erika oils, at two environmental concentrations, 3 and $10 \mathrm{\mu g} \mathrm{g}^{-1}$ sum of PAHs. The degree and spectrum of toxicity were different according to the extract considered. Acute effects including embryo mortality and decreased hatching success were observed only for Erika oil extract. Arabian Light and pyrolytic extracts induced mainly sublethal effects including reduced larvae size and hemorrhages. Arabian Light and Erika extracts both induced repairable DNA damage as revealed by the comet assay versus the micronucleus assay. The concentration and proportion of methylphenanthrenes and methylanthracenes appeared to drive the toxicity of the three $\underline{P A H}$ fractions tested, featuring a toxic gradient as follows: pyrolytic<Arabian Light< Erika. The minimal concentration causing developmental defects was as low as $0.7 \mathrm{\mu g} \mathrm{g}^{-1}$ sum of PAHs, indicating the high sensitivity of the assay and validating its use for toxicity assessment of particle-bound pollutants.
\end{abstract}

Keywords: PAH mixture ; Oil extract ; Pyrolytic extract ; Embryotoxicity ; Developmental defects ; Genotoxicity 


\author{
Abbreviations: \\ PAH : polycyclic aromatic hydrocarbon; \\ AhR : aryl hydrocarbon receptor \\ DD : degree day \\ Dw :dry weight \\ BaP : benzo[a]pyrene \\ Fluo : fluoranthene \\ ELS : early life stage \\ MN : micronucleus \\ PY : pyrolytic \\ LO : Arabian Light oil \\ $\mathrm{HO}$ : Erika heavy oil
}

\title{
1. Introduction
}

Aquatic ecosystems are continuously facing inputs of polycyclic aromatic hydrocarbons (PAHs) of different origins. PAHs sources of contamination are chronic due mainly to human activities such as industry, transport, wood and oil-fired heating or accidental with numerous oil spill accidents, as those involving the Erika, Prestige and Exxon Valdez tankers or more recently the Deep-water Horizon oil spill. Because of their hydrophobicity, PAHs accumulate in sediments over time, which in turn become a continuous source of exposure for benthic organisms.

Fish embryos and eleutheroembryos (yolk fry) are sensitive to a large range of chemicals (Embry et al. 2010; Belanger et al. 2010). Moreover they are also suitable models for chemical testing since they are not covered by the EU regulations on animal experimentation (EC 2010). Among others, salmonids are widely used model species in ecotoxicology (Hawkins et al. 2002; Cook et al. 2003; Carls and Thedinga 2010). They are also suitable species for mesocosm and field studies (Escarti and Porte 1999; Brinkmann et al. 2013). Rainbow trout (Oncorhynchus mykiss) presents several further advantages as being commercially available, easy breeding, having low basal embryo mortality in laboratory settings (below $10 \%$ ), a fully documented development and a high sensitivity to pollutants in particular PAHs - at early life stages (Brinkworth et al. 2003; Hodson et al. 2007). 
PAHs occur in complex mixtures in the environment, their composition and toxicity vary markedly depending on their sources: pyrolytic, diagenetic or petrogenic ( Wang et al. 2003; Barbee et al. 2008). The additive toxicity of PAH compounds in complex mixtures is a controversial subject. Recent studies disprove the aryl hydrocarbon receptor (AhR) agonist approach to estimate PAH mixture toxicity (Incardona et al. 2005; Billiard et al. 2008). In this study, an embryo-larval assay was developed to compare the toxicity of PAH mixtures of different compositions, to Oncorhynchus mykiss early life stages (ELS). Taking into consideration the natural spawning conditions of salmonids and the poor solubility of PAH in water, the assay was based on direct exposure to PAH-spiked gravel at realistic environmental concentrations. Although aquatic organisms seem to be more sensitive to dissolved PAH (Geffard et al. 2003; Carls and Meador 2009), other studies underlined the evident contribution of the sediment for fish embryo contamination (Kocan et al. 1996). Compared to classical embryolarval assays using waterborne exposure, this assay mimics the double exposure of fish embryos via the aqueous phase, the pore water and direct contact with contaminated sediment particles.

The experimental design was firstly tested using two model PAHs, fluoranthene and benzo[a]pyrene. Those two compounds were selected for their high capacity to adsorb onto particles, and their ubiquity in aquatic environment (Guasch et al. 2012). The validated experimental design was then applied for toxicity comparison of three different PAH fractions to rainbow trout ELS: 1) a pyrolytic PAH fraction (PY) from a contaminated sediment of the Seine river, 2) an Arabian Light oil PAH fraction (LO) and 3) an Erika oil PAH fraction (HO). Several endpoints were recorded including survival, hatching delay, hatching success, biometry, developmental defects and DNA damage measured by the comet and the micronucleus assays.

\section{Materials \& methods}

\subsection{PAH fraction samples}

The pyrolytic PAH fraction (PY) was obtained from a superficial sediment (oxic layer) of the Seine River, sampled in March 2010 in Oissel, (Normandy, France). CEDRE (Center of Documentation, Research and Experimentation on Accidental Water Pollution) provided both the Arabian Light oil (LO) and the Erika heavy oil (HO). PY fraction was extracted using pressurized liquid extraction with dichloromethane (Acros Organics, Thermo Fisher Scientific, Geel, Belgium). The two oils were dissolved in pentane to induce asphaltene precipitation. The sediment extract and the two pentane extracts were then reconcentrated using a Vacuum 
Evaporation System (Rapidvap, Labconco, Kansas city, USA). All three PAH samples were then purified using alumina columns (preparative liquid chromatography) and eluted with dichloromethane (Acros Organics, Thermo Fisher Scientific, Geel, Belgium). After another re-concentration step, aliphatic fractions obtained after elution on silica columns with pentane were discarded and aromatic fractions were obtained using pentane/dichloromethane (65/35, v/v) as solvents. Atlantic Labo (Bruges, France) provided the pentane solvent. Finally, samples were re-concentrated and the final fractions kept in dichloromethane (stored at $-20{ }^{\circ} \mathrm{C}$ ) for spiking experiments. All the steps were gravimetrically controlled in order to prevent PAH losses and also to be able to express results in terms of quantity of the initial material (i.e. sediment or petroleum).

\subsection{Gravel spiking}

Silica gravel of 2-4 mm size was provided by Sibelco sandpit (gravel reference BB 2/4, Mios, France). It was washed in $\mathrm{HCl}(1 \%, \mathrm{v} / \mathrm{v})$ and rinsed with reverse osmosis water before use. The clean gravel $(50 \mathrm{~g} d w)$ was then spiked with $100 \mathrm{~mL}$ of dichloromethane (Biosolve, Valkenswaard, the Netherlands) used as a spiking solvent or individual PAHs alone or in mixture in a $1 \mathrm{~L}$ glass flask using a rotary evaporator (Rotavapor, IKA, Staufen, Germany). For validation of the experimental design, the gravel was spiked with $3000 \mathrm{ng} \mathrm{g}^{-1} \mathrm{dw}$ of benzo[a]pyrene $(\mathrm{BaP})$ or fluoranthene (Fluo) (Sigma-Aldrich, St Quentin Fallavier, France). For PAH fraction testing, the gravel was spiked with $0.3 \mathrm{X}$ and $1 \mathrm{X}$ concentrations of each $\mathrm{PAH}$ fraction. $1 \mathrm{X}$ concentration refers to the total PAH content in sediment from the upper Seine estuary e.g. $10000 \mathrm{ng} \mathrm{g}^{-1} \mathrm{dw}$ (Cachot et al. 2006). Solvent was evaporated at $45{ }^{\circ} \mathrm{C}, 115 \mathrm{rpm}$ for $2 \mathrm{~h}$. An aliquot of the spiked gravel was stored at $-20{ }^{\circ} \mathrm{C}$ in anticipation of chemical analysis. Remaining spiked gravel (40 $\mathrm{g} \mathrm{dw})$ was kept in the dark and at room temperature prior to the assay.

\subsection{Chemical analysis}

Internal deuterated standards naphthalene d8 (EGA-CHEMIE), dibenzo[b,d]thiophene d8 (MSD isotopes), phenanthrene d10 (Cambridge Isotope Laboratories), anthracene d10 (Cambridge Isotope Laboratories), fluoranthene d10 (MSD isotopes), chrysene d12 (MSD isotopes), benzo[e]pyrene d12 (Cluzeau - CDN Isotopes), benzo[a]pyrene d12 (Cambridge Isotope Laboratories), and benzo[ghi]perylene d12 (Cambridge Isotope Laboratories) were added prior to extraction, to $1 \mathrm{~g}$ of gravel and one blank analysis composed of 
extraction solvent only. PAH compounds were extracted for $10 \mathrm{~min}$ at $30 \mathrm{~W}$ using microwaves assisted extraction, with dichloromethane as solvent (Budzinski et al. 2000). Samples were then re-concentrated using a Vacuum Evaporation System (Rapidvap, Labconco, Kansas City, USA). Re-concentrated extract samples were purified using alumina micro-columns and eluted with $3 \times 5 \mathrm{~mL}$ of dichloromethane. After a new reconcentration with gas nitrogen, the aliphatic fraction was eluted on silica micro-columns using pentane/dichloromethane $(65 / 35, \mathrm{v} / \mathrm{v})$ as solvents. Finally, samples were re-concentrated in isooctane (Scharlau, Barcelona, Spain). Pyrene d10 and benzo[b]fluoranthene d12, both supplied by Cambridge Isotope Laboratories, were added to the samples as syringe standards before injection. PAHs were analysed by gas chromatography coupled to mass spectrometry (GC-MS) as described by Baumard et al. (1998) and included 21 parent compounds: naphthalene, acenapthylene, acenaphthene, fluorene, dibenzo[bd]thiophene, phenanthrene, anthracene, fluoranthene, pyrene, benz $[a]$ anthracene, triphenylene, chrysene, benzo[ $b]$ naphto $[2,1-d]$ thiophene, benzo $[b+k+j]$ fluoranthene, benzo[e]pyrene, benzo[a]pyrene, perylene, indeno[1,2,3-cd]pyrene, dibenzo $[a h]$ anthracene, dibenzo $[a c]$ anthracene, benzo[ghi]perylene; as well as methyl compounds: 2methylnaphthalene, 1-methylnaphthalene, 3-methylphenanthrene, 2-methylphenanthrene, 2-methylanthracene, 9methylphenanthrene+2-methylanthracene, 1-methylphenanthrene, 4-methyldibenzothiophene, 3+2methyldibenzothiophenes, 1-methyldibenzotiophene, dimethylnaphthalenes, trimethylnaphthalenes, tetramethylnaphthalenes, dimethylphenanthrenes, trimethylphenanthrenes, methylchrysenes. Extraction recoveries calculated with internal and syringe standards were overall very satisfactory, equivalent on average to $87 \%$. Limits of quantification were evaluated for each PAH compound using the peak to peak method of calculation.

\subsection{Experimental set up validation}

131 To ensure a suitable time period for exposure and stabilized dissolved oxygen concentration, several 132 experimental designs were tested including dynamic water renewal, static daily water renewal, and static water (water not renewed). Since there was no marked difference in trout development according to the experimental design (unpublished data), exposure was set from the eyed stage until the hatching stage in static water conditions in order to limit wash-out of spiked-gravel. To validate this experimental design, a preliminary experiment was performed exposing embryos to two model PAHs, BaP and Fluo. 
INRA-PEIMA (Sizun, France) provided rainbow trout embryos at eyed stage, e.g. 180 degree day (DD : number of days $\mathrm{x}$ temperature). Each treatment was replicated 3 times. For each single replicate, 25 embryos were laid in a $100 \mathrm{~mL}$ glass jar containing $12 \mathrm{~g} \mathrm{dw}$ of spiked gravel and $50 \mathrm{~mL}$ of Saint Martin spring water, dechlorinated with $48 \mathrm{~h}$ aeration (St Martin de Gurçon, France, $\mathrm{pH}=8.2 ; 68 \mathrm{mg} \mathrm{L}^{-1} \mathrm{Ca}^{2+} ; 21 \mathrm{mg} \mathrm{L} \mathrm{Na}^{2+} ; 11 \mathrm{mg} \mathrm{L}^{-1} \mathrm{Mg}^{2+} ; 2$

\subsection{Phenotypic effects}

Embryonic and larval survival was recorded daily. Dead individuals were immediately removed to avoid water alteration. Individuals were considered half-hatched if at least a part of the embryonic body remained inside the chorion. Embryonic, larval or half-hatched mortality refers to the number of dead individuals at the end of the experiment compared to the total number of individuals at the beginning (180 DD). Hatching time refers to the number of DD from fertilization to hatching.

Occurrence of developmental abnormalities were microscopically examined on 15 larvae per replicate between 0 and $24 \mathrm{~h}$ post hatching. The larvae under examination were laid on a Petri dish containing $1.5 \%$ agarose gel (LB Agar) and $2 \mathrm{~mL}$ of spring water. Larvae were photographed at X20 magnification using a stereomicroscope MZ 7.5 Leica coupled with a CCD camera DFP420C Leica (Nanterre, France) and a cold light source source (Intralux ${ }^{\circledR} 4100$, Volpi AG, Schlieren, Switzerland). Total body length and head length of larvae were measured 
using Leica Microsystems software v3.8 (Nanterre, France). Six types of abnormality were recorded in larvae: edemas (yolk sac, pericardia or skeletal); spinal (scoliosis, lordosis, or cyphosis) and craniofacial (skull and jaw shape deformities) deformities; cardiac anomalies (changes in heart location and ventricle size); hemorrhages (located on the skeleton, yolk sac, skull, or jaw); and yolk sac resorption defects. Abnormal larvae rate referred to the percentage of abnormal larvae presenting at least one type of abnormality. Edema, spinal, craniofacial, cardiac hemorrhage and yolk sac abnormality rates referred to the percentage or larvae presenting one or several abnormalities, counted once. One larva could exhibit several types of abnormalities.

\subsection{Genotoxic effects}

Genotoxicity assays were performed on 350 DD larvae. Peripheral blood from 5 individuals per replicate treatment was sampled with heparinized tips via cardiac puncture, and mixed immediately with $1 \mathrm{~mL}$ of Minimum Essential Medium Eagle (MEM) (Sigma-Aldrich, St Quentin Fallavier, France). Cell viability was assessed with Trypan blue exclusion as above $90 \%$ in all samples and cell concentration at around $500 \mathrm{cell}_{\mu \mathrm{L}}^{-1}$. Cells used for comet and micronucleus assays were from the same cell suspension sample.

For the comet assay, the protocol of Singh et al. (1988) was followed. $50 \mu \mathrm{L}$ of cell suspension was added to 100 $\mu \mathrm{L}$ of $1 \%(w / w)$ low melting point agarose (LMPA) and two $50 \mu \mathrm{L}$ gels were laid on slides previously covered with normal melting point agarose $(1 \%$, w/w). Gels were shielded with an 18 x $18 \mathrm{~mm}$ glass slip and hardened for $5 \mathrm{~min}$ at $4^{\circ} \mathrm{C}$. Cover slips were gently slid off and a second LMPA only gel was laid on each of the first gels shields with a new coverslip. After hardening for 5 min again at $4{ }^{\circ} \mathrm{C}$, coverslips were slid off and slides were placed in a freshly prepared lysis solution at $4{ }^{\circ} \mathrm{C}$ for $1 \mathrm{~h}(2.5 \mathrm{M} \mathrm{NaCl} ; 0.1 \mathrm{M}$ EDTA; $0.01 \mathrm{M}$ Tris; $\mathrm{pH}$ adjusted to 10 with $\mathrm{NaOH}$ ). One percent of Triton X-100 was added to the solution extemporaneously. Slides were then placed on a horizontal electrophoresis tray and covered with freshly prepared electrophoresis buffer $(0.3 \mathrm{M}$ $\mathrm{NaOH}$; $1 \mathrm{mM}$ EDTA; $\mathrm{pH}>13$ ) for 10 min to allow the DNA to unwind. Electrophoresis was carried out at $25 \mathrm{~V}$, $300 \mathrm{~mA}$ for $10 \mathrm{~min}$. Subsequently, slides were rinsed three times in a staining tray with neutralization solution $(0.4 \mathrm{M}$ Tris; $\mathrm{pH}=7.5)$ for $5 \mathrm{~min}$ at $4{ }^{\circ} \mathrm{C}$. Finally slides were dehydrated in absolute ice-cold ethanol for a further $20 \mathrm{~min}$ and dried at room temperature. Before reading, slides were stained with $20 \mu \mathrm{g} \mathrm{mL}^{-1}$ ethidium bromide. Comet analysis was performed at X400 magnification using an Olympus epi-fluorescent microscope (Olympus, Rungis, France) with an excitation filter of $515-560 \mathrm{~nm}$, a barrier filter of $590 \mathrm{~nm}$, and a grayscale CCD camera (Zeiss, Germany). DNA damage was measured on 100 cells for each sample with Komet 5.5 software 
(Kinetic Imaging, Liverpool, UK) and expressed as percentage tail DNA. Heavily damaged cells were counted as "hedgehogs", referring to apoptotic or necrotic cells (Olive and Banáth 1995).

For the micronucleus (MN) assay, samples were centrifuged (at $1000 \mathrm{rpm}$, for $10 \mathrm{~min}$ at room temperature) and pelleted cells were fixed in $200 \mu \mathrm{L}$ of a mixed solution of acetic acid: methanol $(1: 4, \mathrm{v} / \mathrm{v})$. Cell suspensions were then smeared onto slides and then dried for $24 \mathrm{~h}$ at room temperature. Just before reading, slides were stained with $40 \mu \mathrm{L}$ of acridine orange solution $(0.003 \%$ in PBS) and covered with a glass slip. Reading was processed using an epi-fluorescent microscope at X400 magnification (Olympus, Rungis, France). The frequency of MN cells was manually recorded on 1000 cells per slide using blind review analysis by a single observer. A cell was considered micronucleated if the MN was round-shaped, distinct from main nucleus, its size was less than a third of the main nucleus, and with a similar green staining as the main nucleus (Hayashi et al. 1998). Non-isolated, stacked, more than bi-nucleated or orange-red stained cells were not considered.

\subsection{Statistical analysis}

Each exposure condition was replicated 3 times and each replicate was considered as an independent sample. Data is indicated as mean \pm standard deviation (SD). Normality of the data distribution was tested on data residues using the Shapiro-Wilk test $(\mathrm{p}<0.01)$. Variance homogeneity was evaluated using the Levene test $(\mathrm{p}<$ 0.05). In cases of homogenous variance and normalized data, one-way Anova was performed, followed by the Tukey post-hoc test $(\mathrm{p}<0.05)$. In opposite cases, data was analyzed using the Kruskal-Wallis non parametric test $(\mathrm{p}<0.05)$. Statistical analyses were performed with Statistica software v7.1 (StatSoft, Maisons-Alfort, France). A principal component analysis (PCA) was performed with R software (http://cran.r-project.org/).

\section{Results}

\subsection{Experimental set up validation}

Oxygen saturation ranged between 85.3 and $103.9 \%$ over embryonic exposure. Fluo spiking efficiency was 2.4 fold higher than BaP efficiency and nominal concentrations reached 2.7 and $1.1 \mu \mathrm{g} \mathrm{g}^{-1} \mathrm{dw}$ for Fluo and BaP respectively (Table 1). No significant mortality was observed in any exposure condition. Mortality rate of solvent control embryos, half-hatched individuals and larvae were very low (below $2.2 \%$ ). Only $10.0 \%$ of 
control larvae presented developmental abnormalities. Exposure to $\mathrm{BaP}$ and Fluo induced significantly more abnormal larvae than control solvent. The majority of $\mathrm{BaP}$ and Fluo-induced developmental defects were spinal curvatures and edemas. $\mathrm{BaP}$ and Fluo did not affect larval time to hatch or hatching rate. Given the low mortality and abnormality levels in the solvent control, combined with the significant adverse effects induced by BaP or Fluo exposure, the preliminary experimental set up appeared to be suitable for sensitive toxicity testing of PAH with rainbow trout ELS.

\subsection{Gravel characterization}

Composition of PAH fractions differed in molecule proportions in relation to the number of cycles and the methylation level of PAHs (Table 2). The proportions of individual PAHs in spiked sediments were comparable for the $0.3 \mathrm{X}$ and $1 \mathrm{X}$ concentrations, apart from the $0.3 \mathrm{X}$ PY condition. Indeed, PY spiked gravels were mainly composed of four aromatic ring compounds, representing $36 \%$ and $33 \%$ of $0.3 \mathrm{X}$ and $1 \mathrm{X}$ total PAHs, respectively. LO spiked gravel was mainly composed of two aromatic ring compounds, representing $44 \%$ and $60 \%$ of $0.3 \mathrm{X}$ and $1 \mathrm{X}$ total PAHs, respectively. HO spiked gravel was mainly composed of three ring compounds representing $54 \%$ and $50 \%$ of $0.3 \mathrm{X}$ and $1 \mathrm{X}$ total PAHs, respectively. Spiking efficiencies ranged between $40 \%$ and $50 \%$, apart from $0.3 \mathrm{X}$ LO gravel which yielded $24 \%$.

\subsection{Developmental toxicity of PAH fractions}

Dissolved oxygen concentrations varied between $80 \%$ and $103 \%$ over embryonic exposure. No significant embryonic or larval mortality was observed during exposure to PAH fractions (Table 3). No statistical difference was detected between control groups incubated in water only or to solvent-spiked gravel. Water and solvent control mortalities were below $3.9 \%$. Embryonic or larval mortality and time to hatch were not affected by PAH exposure. In contrast, half-hatched embryos frequency was significantly increased after exposure to $0.3 \mathrm{X}$ LO $(10.7 \%)$ and $1 \mathrm{X}$ HO $(14.7 \%)$ and $1 \mathrm{X}$ HO reduced significantly hatching success by $28 \%$. In addition, LO and HO treatments but not PY had significant effects on larvae biometry. Larvae exposed to LO and HO were 0.8 $\mathrm{mm}$ and $1.4 \mathrm{~mm}$ shorter than solvent-exposed larvae, respectively (Fig. 1A). LO and HO-exposed larvae had a smaller head with head length reduction by $6.5 \%, 7.2 \%$ and $8.8 \%$, for $1 \mathrm{X} \mathrm{LO}, 0.3 \mathrm{X}$ and $1 \mathrm{X}$ HO treatments, respectively (Fig. 1B). Finally, all PAH fractions significantly impaired normal embryo-larval development. For 
$1 \mathrm{X} \mathrm{HO}, 100 \%$ of larvae presented at least one type of abnormality compared with $82.2 \%$ for 1 X LO and $68.9 \%$ for 1X PY fraction (Table 3). There was no treatment effect on yolk sac resorption with on average $9.3 \%$ of individuals exhibiting yolk sac anomalies (Fig. 2A). About $72.4 \%$ of 1 X HO larvae had a spinal curvature, 66.1 $\%$ craniofacial abnormalities, $29.3 \%$ cardiac anomalies and $56.6 \%$ edema (Fig. 2B, 2C, 2D\& 2E). Furthermore, all three PAH fractions significantly induced hemorrhages from $44.4 \%$ for PY-exposed larvae to $91.1 \%$ for HO-exposed larvae (Fig. 2F).

\subsection{Principal Component Analysis of PAH fractions toxicity}

The selected PCA featured $85.1 \%$ of nine variable variances: five toxicity endpoints and four PAH gravel concentrations (Fig. 4A). Along axis 1 (70.0\%), comet assay, developmental abnormalities and half-hatched embryos variables, with high normalized coefficients, were negatively correlated to hatching rate and total larvae length variables. Moreover, the toxicity of PAH fractions - featured by these five toxicity variables - were positively correlated (comet assay, percentage of deformities and half-hatched embryos) or negatively correlated (hatching rate and total larvae length) to the methylphenantrene concentration especially. In contrast, the toxicity variables were not correlated to the methyldibenzothiophene concentration. The plot of scores for each replicate revealed no overlapping treatment group and a toxicity gradient along axis 1 as following: solvent control $<0.3 \mathrm{X}$ $\mathrm{PY}<1 \mathrm{X}$ PY $<0.3 \mathrm{X}$ LO $=0.3 \mathrm{X}$ HO $<1 \mathrm{X}$ LO $<1 \mathrm{X}$ HO (Fig.4B). Low toxic fractions are located on the left negative side of axis 1 while high toxic fractions are located on the opposite side. 


\section{Discussion}

In this paper a new gravel-contact exposure protocol was specifically designed for toxicity assessment of hydrophobic pollutants on rainbow-trout embryos. Dissolved oxygen remained high in the different assays although no water renewal was made during the experiment. Furthermore, low mortality and abnormality rates were observed in control conditions, while exposed larvae exhibited significant developmental abnormalities. Incubation of trout embryos in direct contact to non-spiked or solvent-spiked gravels did not affect embryonic development. Therefore, the experimental design with direct exposure to spiked gravels and no water renewal appeared suitable for toxicity testing of chemicals with rainbow trout ELS.

Despite a lower Log Kow, Fluo was shown to better adsorb onto gravels than BaP. Liu et al. (2011) have shown that PAHs adsorption on inorganic particles including quartz sand probably follows the Langmuir equation and is related to the hydrophobicity of the compound. Our unexpected result might be explained by the singular nature of the gravel which is exclusively composed of silica grains of relatively large size (2-4 mm). The low specific surface area of the studied gravel might favor sorption of smaller size molecules such as Fluo (4 rings, MW 202.25) instead of larger ones such as BaP (5 rings, MW 252.31).

The PAH composition of the three fractions was well reproduced in the different spiked gravels except for the 0.3X PY-spiked gravel for which four ring compounds adsorbed much better than for the $1 \mathrm{X}$ PY-spiked gravel. This may be due to the loss of low molecular weight compounds during the spiking process. PAH fractions mainly induced sublethal effects in embryos and larvae including cardio-vascular defects and reduced growth for PY and LO conditions. Our observations support recent studies reporting embryotoxicity in rainbow trout ELS after exposure to PAH-contaminated sediment extracts (Sundberg et al. 2005; Karlsson et al. 2008); and juvenile mullet after exposure to LO (Milinkovitch et al. 2011b). Milinkovitch et al. (2011a; 2011b; 2013) also reported bioaccumulation of PAHs in muscle and increased levels of PAH metabolites as well as cardiac toxicity after fish exposure to LO crude oil and its water soluble fraction. Numerous studies about the toxicity of the Alaska North Slope Crude Oil (ANSCO) on pink salmon, herring, mummichog and zebrafish, reported the induction of blue sac disease syndrome, including pericardial edemas, haemorrhages, spinal deformities as well as reduced growth ( Heintz et al. 1999; Couillard 2002; Barron et al. 2003; Hicken et al. 2011). The HO displayed a comparable PAH composition and featured a similar spectrum of developmental defects to the ANSCO. Nevertheless, no developmental delay was observed after rainbow trout ELS exposure to HO or LO extracts. 
Petrogenic fractions but not pyrolytic one also resulted in a significant increase of tail DNA in peripheral blood cells from exposed larvae. Comet assay detects repairable DNA damages such as single/double strand breaks and also alkali labile sites. Comet assay in fish blood cells have been shown to be a sensitive and convenient assay to measure DNA damage induced by genotoxic pollutants in aquatic environment (De Andrade et al 2004; Frenzilli et al, 2009). Conversely, no significant increase of micronucleated blood cells was observed. The MN assay measures irreversible DNA damage, resulting from clastogenic (chromosomal breakage) or aneugenic events (mitotic spindle dysfunction) occurring later in the time course of the mutagenesis process (Udroiu 2006). We can assume that when MN assay was performed (350 DD), DNA damage may not have been definitively fixed in the larva blood cells. These results can be explained by the kinetics of induction and repair of DNA strand breaks (Carls et al. 1999; Nahrgang et al. 2010) but also by the low mitotic index of peripheral blood cells (Fujiwara et al. 2001; Wang et al. 2010).

It is likely that PAH metabolites and reactive oxygen species may be responsible for the DNA damage recorded in this study (Regoli et al. 2002; Fallahtafti et al. 2012). We could expect MN, mutations and tumors induction at later developmental stages as reported after fish exposure to Erika oil, Statfjord oil, or organic extract from the Seine river sediment (Amat et al. 2006; Baršienè et al. 2006; Cachot et al. 2007). However, aromatic extracts may also contain traces of other chemicals which can also be toxic to fish in particular saturated hydrocarbons or mono-aromatic compounds (González-Doncel et al. 2008). In fact, Arabian light crude oil contains $75 \%$ of saturated hydrocarbons, $15 \%$ of aromatic hydrocarbons and $10 \%$ of resins and asphaltenes (Wang et al. 2003). Erika oil contains $22 \%$ of saturated hydrocarbons, $42 \%$ of aromatic hydrocarbons and $35 \%$ of resins and asphaltenes (Baars 2002). Although most of them were removed during the extraction process, some traces may remain in the aromatic fraction.

Toxicity did not increase linearly with increasing proportions of high molecular weight PAHs. Indeed, the PY fraction which contains a high proportion of high molecular weight PAHs was the least toxic mixture to rainbow trout ELS. The LO fraction, mainly composed of two and three ring PAHs, was moderately toxic. Finally, the HO fraction, mainly composed of two to four ring PAHs, was the most toxic fraction. The toxicity gradient illustrated in figure $4 \mathrm{~B}$, highlights differences in toxicity according to the proportion and concentration in methylated phenanthrenes and methylated anthracenes. Genotoxicity and developmental toxicity of the PAH mixtures are mainly driven by the concentration and proportion of three ring methylated-PAHs that predominate in the HO fraction. It is now well documented that different PAH compounds have different modes of action and toxicity that are assumed not to be additive (Billiard et al. 2008). Low molecular weight PAHs act preferentially 
through the narcosis pathway while high molecular weight PAHs involve binding to aryl hydrocarbon receptor AhR (Di Toro et al. 1991; Wassenberg and Di Giulio 2004). It has been recently demonstrated that three ring compounds can also act through an unknown AhR-independent pathway ( Hawkins et al. 2002; Incardona et al. 2005). Previous works reported the highest toxicity to fish ELS of three ring compounds either alone (Incardona et al. 2004) or in mixture (Sundberg et al. 2005; Incardona et al. 2009). Based on their embryo-larval toxicity, an alkyl-phenanthrene model was recently developed on methylated-phenanthrene from two to four carbons to better evaluate the complex toxicity of PAH mixtures (Barron et al. 2004). Alkyl-phenanthrenes toxicity can be explained 1) by indirect toxicity due to reactive oxygen species production and 2) by direct toxicity of the compound itself or its metabolites (Billiard et al. 2008). Indeed, biotransformation of alkyl-phenanthrenes generates highly toxic metabolites by hydroxylation on double bonds of rings or on the alkyl side chains. These molecules are able to disrupt the cellular homeostasis resulting in cytotoxicity directly related to the genotoxic potency of the compound (Burczynski and Penning 2000). Para substituted quinones appear to be one of the most toxic hydroxylated metabolites of alkyl-phenanthrenes to fish ELS (Fallahtafti et al. 2012).

In an ecological point of view, the exposure conditions in our experiments are consistent with the natural habitat conditions of salmonid embryos and environmental concentrations of PAHs in contaminated sediments (Cachot et al. 2006; Karlsson et al. 2008). Indeed, salmonid embryos are usually buried into the gravel of the river bed throughout their embryonic development. This exposure design did not consider the phototoxicity of PAHs since embryos were incubated in complete darkness. This could have led to underestimating PAH toxicity to rainbow trout ELS (Barron et al. 2003; Hatlen et al. 2010).

It was shown here that direct exposure of rainbow trout ELS to spiked gravels is a suitable approach to assess toxicity of PAHs. Further experiments will be carried out to validate this approach with other hydrophobic pollutants.

\section{Conclusion}

To summarize, this study succeeded in designing a suitable and environmentally realistic protocol for hydrophobic compound testing with Oncorhynchus mykiss ELS. Teratogenic and genotoxic effects of three PAH mixtures were reported. Toxicity of PAH mixtures was positively related to the concentrations of 
methylphenanthrenes and methylanthracenes. Our data support PAH mixtures containing high amount of alkylphenanthrenes are likely a threat for fish early life stages.

\section{Acknowledgments}

This work was funded by the French National Agency for Research, program "Contaminant, Ecosystème et Santé", in the frame of the ConPhyPoP (2009-002) research project. Equipment was funded by GDR EXECO, Aquitaine Region and CPER A2E. This project is co-financed by the European Union with the European fund of regional development. Florane Le Bihanic received a $\mathrm{PhD}$ fellowship from the French Ministère de l'Enseignement Supérieur et de la Recherche. The authors wish to thank CEDRE for providing the oils used in this study. This work was part of the LABEX COTE cluster of excellence continental to coastal ecosystems.

\section{References}

Amat A, Burgeot T, Castegnaro M, Pfohl-Leszkowicz A (2006) DNA adducts in fish following an oil spill exposure. Environ Chem Lett 4 (2):93-99

Baars B-J (2002) The wreckage of the oil tanker "Erika" - human health risk assessment of beach cleaning, sunbathing and swimming. Toxicol Lett 128 (1-3):55-68. doi:http://dx.doi.org/10.1016/S0378$\underline{4274(01) 00533-1}$

Barbee GC, Barich J, Duncan B, Bickham JW, Matson CW, Hintze CJ, Autenrieth RL, Zhou G-D, McDonald TJ, Cizmas L, Norton D, Donnelly KC (2008) In situ biomonitoring of PAH-contaminated sediments using juvenile coho salmon (Oncorhynchus kisutch). Ecotoxicol Environ Saf 71 (2):454-464

Barron MG, Carls MG, Heintz R, Rice SD (2004) Evaluation of Fish Early Life-Stage Toxicity Models of Chronic Embryonic Exposures to Complex Polycyclic Aromatic Hydrocarbon Mixtures. Toxicol Sci 78 (1):60-67. doi:10.1093/toxsci/kfh051

Barron MG, Carls MG, Short JW, Rice SD (2003) Photoenhanced toxicity of aqueous phase and chemically dispersed weathered alaska north slope crude oil to pacific herring eggs and larvae. Environ Toxicol Chem 22 (3):650-660 
Baršienė J, Dedonytė V, Rybakovas A, Andreikènaitė L, Andersen OK (2006) Investigation of micronuclei and other nuclear abnormalities in peripheral blood and kidney of marine fish treated with crude oil. Aquat Toxicol 78, Supplement (0):S99-S104. doi:http://dx.doi.org/10.1016/j.aquatox.2006.02.022

Baumard P, Budzinski H, Garrigues P (1998) PAHs in Arcachon Bay, France: Origin and biomonitoring with caged organisms. Mar Pollut Bull 36 (8):577-586. doi:http://dx.doi.org/10.1016/S0025-326X(98)00014$\underline{9}$

Belanger SE, Balon EK, Rawlings JM (2010) Saltatory ontogeny of fishes and sensitive early life stages for ecotoxicology tests. Aquat Toxicol 97 (2):88-95

Billiard SM, Meyer JN, Wassenberg DM, Hodson PV, Di Giulio RT (2008) Nonadditive effects of PAHs on early vertebrate development: mechanisms and implications for risk assessment. Toxicol Sci 105 (1):523. doi:10.1093/toxsci/kfm303

Brinkmann M, Hudjetz S, Kammann U, Hennig M, Kuckelkorn J, Chinoraks M, Cofalla C, Wiseman S, Giesy JP, Schäffer A, Hecker M, Wölz J, Schüttrumpf H, Hollert H (2013) How flood events affect rainbow trout: Evidence of a biomarker cascade in rainbow trout after exposure to PAH contaminated sediment suspensions. Aquat Toxicol 128-129 (0):13-24. doi:http://dx.doi.org/10.1016/j.aquatox.2012.11.010

Brinkworth LC, Hodson PV, Tabash S, Lee P (2003) CYP1A induction and blue sac disease in early developmental stages of rainbow trout (Oncoryhchus mykiss) exposed to retene J Toxicol Environ Health, A 66:627-646

Budzinski H, Letellier M, Thompson S, Le Menach K, Garrigues P (2000) Combined protocol for the analysis of polycyclic aromatic hydrocarbons (PAHs) and polychlorobiphenyls (PCBs) from sediments using focussed microwave assisted (FMW) extraction at atmospheric pressure. Fresenius J Anal Chem 367 (2):165-171. doi:10.1007/s002160051618

Burczynski ME, Penning TM (2000) Genotoxic polycyclic aromatic hydrocarbon ortho-quinones generated by aldo-keto reductases induce CYP1A1 via nuclear translocation of the aryl hydrocarbon receptor. Cancer Res 60 (4):908-915

Cachot J, Geffard O, Augagneur S, Lacroix S, Le Menach K, Peluhet L, Couteau J, Denier X, Devier MH, Pottier D, Budzinski H (2006) Evidence of genotoxicity related to high PAH content of sediments in the upper part of the Seine estuary (Normandy, France). Aquat Toxicol 79 (3):257-267 
Cachot J, Law M, Pottier D, Peluhet L, Norris M, Budzinski H, Winn R (2007) Characterization of toxic effects of sediment-associated organic pollutants using the $\lambda$ transgenic medaka. Environ Sci Technol 41 (22):7830-7836

Carls MG, Meador JP (2009) A Perspective on the Toxicity of Petrogenic PAHs to Developing Fish Embryos Related to Environmental Chemistry. Hum Ecol Risk Assess 15(6):1084-1098.

Carls MG, Rice SD, Hose JE (1999) Sensitivity of fish embryos to weathered crude oil: Part I. Low-level exposure during incubation causes malformations, genetic damage, and mortality in larval pacific herring (Clupea pallasi). Environ Toxicol Chem 18 (3):481-493. doi:10.1002/etc.5620180317

Carls MG, Thedinga JF (2010) Exposure of pink salmon embryos to dissolved polynuclear aromatic hydrocarbons delays development, prolonging vulnerability to mechanical damage. Mar Environ Res 69 $(5): 318-325$

Cook PM, Robbins JA, Endicott DD, Lodge KB, Guiney PD, Walker MK, Zabel EW, Peterson RE (2003) Effects of aryl hydrocarbon receptor-mediated early life stage toxicity on lake trout populations in Lake Ontario during the 20th century. Environ Sci Technol 37 (17):3864-3877. doi:doi:10.1021/es034045m

Couillard CM (2002) A microscale test to measure petroleum oil toxicity to mummichog embryos. Environ Toxicol 17 (3):195-202. doi:10.1002/tox.10049

Di Toro DM, Zarba CS, Hansen DJ, Berry WJ, Swartz RC, Cowan CE, Pavlou SP, Allen HE, Thomas NA, Paquin PR (1991) Technical basis for establishing sediment quality criteria for nonionic organic chemicals using equilibrium partitioning. Environ Toxicol Chem 10 (12):1541-1583. doi:10.1002/etc.5620101203

De Andrade VM, De Freitas, TRO, Da Silva, J (2004) Comet assay using mullet (Mugil sp.) and sea catfish (Netuma sp.) erythrocytes for the detection of genotoxic pollutants in aquatic environment. Mutat Res Genet Toxicol Environ Mutagen 560(1) : 57-67

EC (2010) Directive 2010/63/EU of the european parliament and of the council of 22 September 2010 on the protection of animals used for scientific purposes. vol L276. Official Journal of the European Union,

Embry MR, Belanger SE, Braunbeck TA, Galay-Burgos M, Halder M, Hinton DE, Léonard MA, Lillicrap A, Norberg-King T, Whale G (2010) The fish embryo toxicity test as an animal alternative method in hazard and risk assessment and scientific research. Aquat Toxicol 97 (2):79-87

Escarti E, Porte C (1999) Biomonitoring of PAH pollution in high-altitude mountain lakes through the analysis of fish bile, vol 33. American Chemical Society, Washington, DC, ETATS-UNIS 
Fallahtafti S, Rantanen T, Brown RS, Snieckus V, Hodson PV (2012) Toxicity of hydroxylated alkylphenanthrenes to the early life stages of Japanese medaka (Oryzias latipes). Aquat Toxicol 106-107 (0):56-64. doi:http://dx.doi.org/10.1016/j.aquatox.2011.10.007

Frenzilli G, Nigro M, Lyons BP (2009) The Comet assay for the evaluation of genotoxic impact in aquatic environments (Review). Mutat Res, Rev Mutat Res 681 (1) : Pages 80-92.

Fujiwara A, Nishida-Umehara C, Sakamoto T, Okamoto N, Nakayama I, Abe S (2001) Improved fish lymphocyte culture for chromosome preparation, Genetica 111:77-89

Geffard O, Geffard A, His E, Budzinski H (2003) Assessment of the bioavailability and toxicity of sedimentassociated polycyclic aromatic hydrocarbons and heavy metals applied to Crassostrea gigas embryos and larvae. Mar Pollut Bull 46(4):481-49González-Doncel M, González L, Fernández-Torija C, Navas JM, Tarazona JV (2008) Toxic effects of an oil spill on fish early life stages may not be exclusively associated to PAHs: Studies with Prestige oil and medaka (Oryzias latipes). Aquat Toxicol 87 (4):280288. doi:http://dx.doi.org/10.1016/j.aquatox.2008.02.013

Guasch H, Ginebreda A, Geiszinger A, Akkanen J, Slootweg T, Mäenpää K, Leppänen M, Agbo S, Gallampois C, Kukkonen JK (2012) Bioavailability of organic contaminants in freshwater environments. In: Emerging and Priority Pollutants in Rivers. The Handbook of Environmental Chemistry. Springer Berlin Heidelberg, pp 25-53. doi:10.1007/978-3-642-25722-3_2

Hatlen K, Sloan CA, Burrows DG, Collier TK, Scholz NL, Incardona JP (2010) Natural sunlight and residual fuel oils are an acutely lethal combination for fish embryos. Aquat Toxicol 99 (1):56-64

Hawkins SA, Billiard SM, Tabash SP, Brown RS, Hodson PV (2002) Altering cytochrome P4501A activity affects polycyclic aromatic hydrocarbon metabolism and toxicity in rainbow trout (Oncorhynchus mykiss). Environ Toxicol Chem 21 (9):1845-1853. doi:10.1002/etc.5620210912

Hayashi M, Ueda T, Uyeno K, Wada K, Kinae N, Saotome K, Tanaka N, Takai A, Sasaki YF, Asano N, Sofuni T, Ojima Y (1998) Development of genotoxicity assay systems that use aquatic organisms. Mutation Research/Fundamental and Molecular Mechanisms of Mutagenesis 399 (2):125-133

Heintz RA, Short JW, Rice SD (1999) Sensitivity of fish embryos to weathered crude oil: Part II. Increased mortality of pink salmon (Oncorhynchus gorbuscha) embryos incubating downstream from weathered Exxon valdez crude oil. Environ Toxicol Chem 18 (3):494-503. doi:10.1002/etc.5620180318

Hicken CE, Linbo TL, Baldwin DH, Willis ML, Myers MS, Holland L, Larsen M, Stekoll MS, Rice SD, Collier TK, Scholz NL, Incardona JP (2011) Sublethal exposure to crude oil during embryonic development 
alters cardiac morphology and reduces aerobic capacity in adult fish. Proceedings of the National Academy of Sciences 108 (17):7086-7090. doi:10.1073/pnas.1019031108

Hodson PV, Qureshi K, Noble CAJ, Akhtar P, Brown RS (2007) Inhibition of CYP1A enzymes by $\beta$ naphthoflavone causes both synergism and antagonism of retene toxicity to rainbow trout

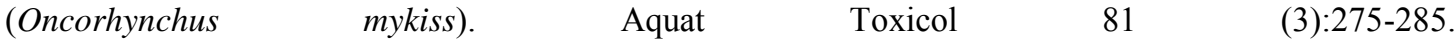
doi:http://dx.doi.org/10.1016/j.aquatox.2006.12.012

Incardona JP, Carls MG, Day HL, Sloan CA, Bolton JL, Collier TK, Scholz NL (2009) Cardiac arrhythmia is the primary response of embryonic pacific herring (Clupea pallasi) exposed to crude oil during weathering. Environ Sci Technol 43 (1):201-207. doi:10.1021/es802270t

Incardona JP, Carls MG, Teraoka H, Sloan CA, Collier TK, Scholz NL (2005) Aryl hydrocarbon receptorindependent toxicity of weathered crude oil during fish development. Environ Health Perspect 113 (12):1755-1762

Incardona JP, Collier TK, Scholz NL (2004) Defects in cardiac function precede morphological abnormalities in fish embryos exposed to polycyclic aromatic hydrocarbons. Toxicol Appl Pharmacol 196 (2):191-205

Karlsson J, Sundberg H, Åkerman G, Grunder K, Eklund B, Breitholtz M (2008) Hazard identification of contaminated sites - ranking potential toxicity of organic sediment extracts in crustacean and fish. J Soils Sed 8 (4):263-274. doi:10.1007/s11368-008-0015-3

Kocan RM, Matta MB, Salazar SM (1996) Toxicity of weathered coal tar for shortnose sturgeon (Acipenser brevirostrum) embryos and larvae. Arch Environ Contam Toxicol 31:161-165.

Liu JJ, Wang XC, Fan B (2011) Characteristics of PAHs adsorption on inorganic particles and activated sludge in domestic wastewater treatment. Bioresource Technology 102:5305-5311

Milinkovitch T, Imbert N, Sanchez W, Le Floch S, Thomas-Guyon H (2013) Toxicological effects of crude oil and oil dispersant: Biomarkers in the heart of the juvenile golden grey mullet (Liza aurata). Ecotoxicol Environ Saf 88 (0):1-8. doi:http://dx.doi.org/10.1016/j.ecoenv.2012.10.029

Milinkovitch T, Kanan R, Thomas-Guyon H, Le Floch S (2011a) Effects of dispersed oil exposure on the bioaccumulation of polycyclic aromatic hydrocarbons and the mortality of juvenile Liza ramada. Sci Total Environ 409 (9):1643-1650. doi:http://dx.doi.org/10.1016/j.scitotenv.2011.01.009

Milinkovitch T, Ndiaye A, Sanchez W, Le Floch S, Thomas-Guyon H (2011b) Liver antioxidant and plasma immune responses in juvenile golden grey mullet (Liza aurata) exposed to dispersed crude oil. Aquat Toxicol 101 (1):155-164. doi:http://dx.doi.org/10.1016/j.aquatox.2010.09.013 
Nahrgang J, Camus L, Carls MG, Gonzalez P, Jönsson M, Taban IC, Bechmann RK, Christiansen JS, Hop H (2010) Biomarker responses in polar cod (Boreogadus saida) exposed to the water soluble fraction of crude oil. Aquat Toxicol 97 (3):234-242. doi:http://dx.doi.org/10.1016/j.aquatox.2009.11.003

Olive PL, Banáth JP (1995) Sizing highly fragmented DNA in individual apoptotic cells using the Comet Assay and a DNA crosslinking agent. Exp Cell Res 221 (1):19-26. doi:http://dx.doi.org/10.1006/excr.1995.1348

Regoli F, Gorbi S, Frenzilli G, Nigro M, Corsi I, Focardi S, Winston GW (2002) Oxidative stress in ecotoxicology: from the analysis of individual antioxidants to a more integrated approach. Mar Environ Res 54:419-423. doi:http://dx.doi.org/10.1016/S0141-1136(02)00146-0

Singh NP, McCoy MT, Tice RR, Schneider EL (1988) A simple technique for quantitation of low levels of DNA damage in individual cells. Exp Cell Res 175 (1):184-191. doi:http://dx.doi.org/10.1016/0014$\underline{4827(88) 90265-0}$

Sundberg H, Ishaq R, Akerman G, Tjarnlund U, Zebuhr Y, Linderoth M, Broman D, Balk L (2005) A bio-effect directed fractionation study for toxicological and chemical characterization of organic compounds in bottom sediment. Toxicol Sci 84 (1):63-72. doi:10.1093/toxsci/kfi067

Udroiu I (2006) The micronucleus test in piscine erythrocytes. Aquat. Toxicol. 79 : 201-204Wang Z, Hollebone BP, Fingas M, Fieldhouse B, Sigouin L, Landriault M, Smith P, Noonan J, Thouin G (2003) Characteristics of spilled oils, fuels, and petroleum products: 1. Composition and properties of selected oils. US EPA

Wang B, Liu Y, Chen X, Fan Z (2010) Amitosis-like nuclear division in erythrocytes of triploid rainbow trout Oncorhynchus mykiss Journal of Fish Biology 76: 1205-1211.doi:10.1111/j.1095-8649.2010.02556.x,

Wassenberg DM, Di Giulio RT (2004) Synergistic embryotoxicity of polycyclic aromatic hydrocarbon aryl hydrocarbon receptor agonists with cytochrome P4501A inhibitors in Fundulus heteroclitus. Environ Health Perspect 112 (17):1658-1664

\section{FIGURE CAPTIONS}

534 Fig. 1: Exposure to PAH fractions affected rainbow trout larvae biometry at hatching. A) Larvae total length; B) 
Fig. 2: Exposure to PAH fractions induced developmental abnormalities in newly hatched rainbow trout larvae. A) Yolk sac resorption anomalies; B) Spinal abnormalities including scoliosis, lordosis, cyphosis; C) Craniofacial deformities including changes in skull and jaw shape ; D) Cardiac anomalies including changes in heart location and ventricle size; E) Edema occurrence; F) Haemorrhage occurrence on skeleton, yolk sac, skull and jaw. Individuals were exposed during embryonic development to chemical-spiked gravels. Different letters refer to significant differences between treatments (Mean $\pm \mathrm{SD}, \mathrm{N}=3$, Anova, $\mathrm{p}<0.05$ ).

Fig. 3: Exposure to PAH fractions induced genotoxicity in rainbow trout larvae. A) Comet assay. DNA damage is expressed in percentage of DNA in the comet tail. B) Micronucleus assay. DNA damage is expressed in micronucleated cell frequency. Individuals were exposed during embryonic development to chemical-spiked gravels. Different letters refer to significant differences between treatments (Mean $\pm \mathrm{SD}, \mathrm{N}=3$, Anova, $\mathrm{p}<$ $0.05)$.

Fig. 4: Methylphenanthrene concentrations drove PAH fractions toxicity in rainbow trout early life stages. A) Variable factor map; B) Individual factor map. PCA representing normalized coefficients on the first two axes (axis 1: $70.0 \%$; axis 2: $15.1 \%$ ) for nine variables: five toxicity variables and four PAH gravel concentrations. Toxicity endpoints referred to HR: Hatching rate; LengthT: Larvae total length; D: Developmental abnormalities; Comet: percentage tail DNA; MortHH: half-hatched mortality. PAH gravels concentrations refer to MP: methylphenanthrene, DMP: dimethylphenanthrene, TMP: trimethylphenanthrenes; MDBT: methyldibenzothiophene. 


\section{Figure 1}
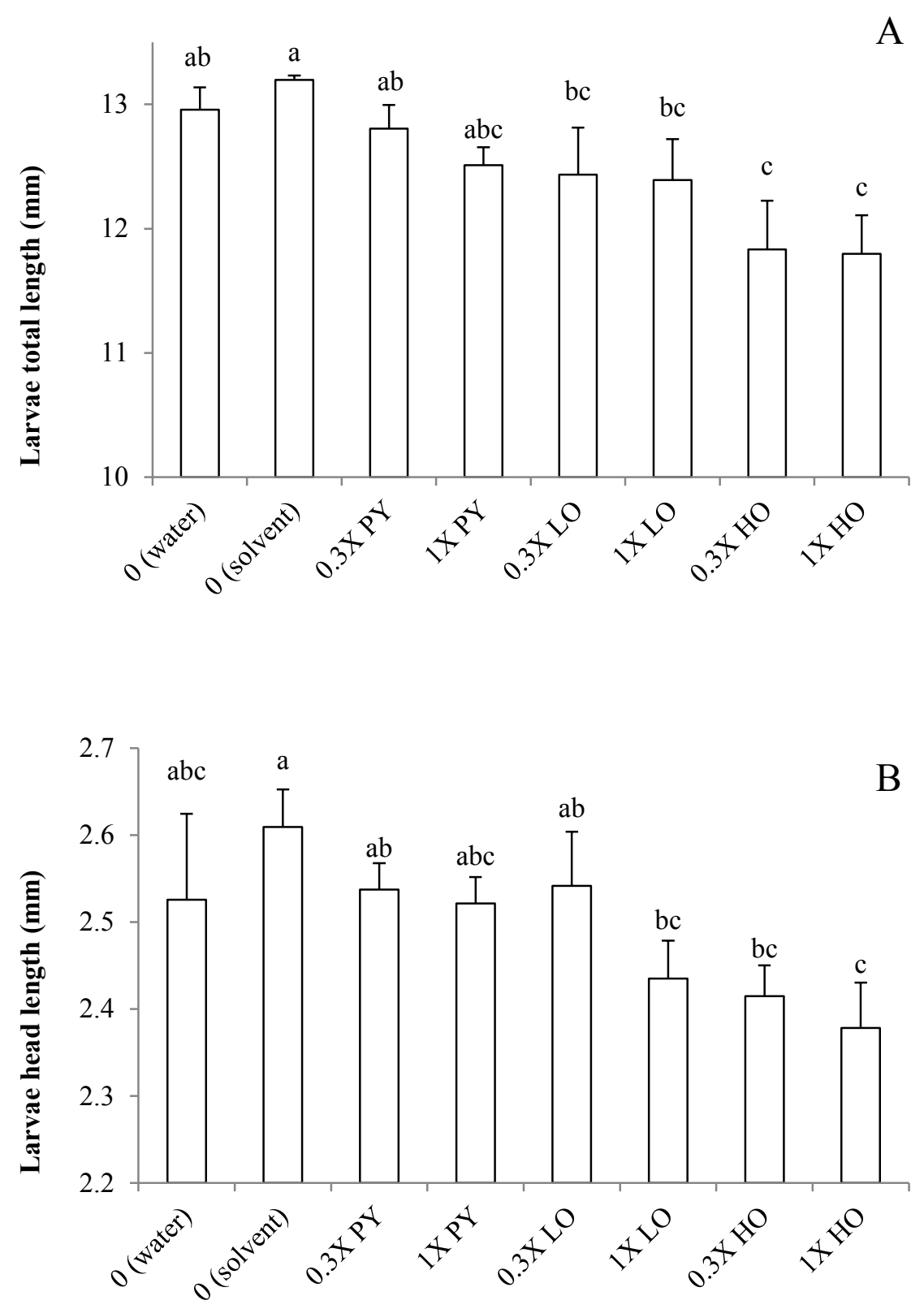


\section{Figure 2}

A

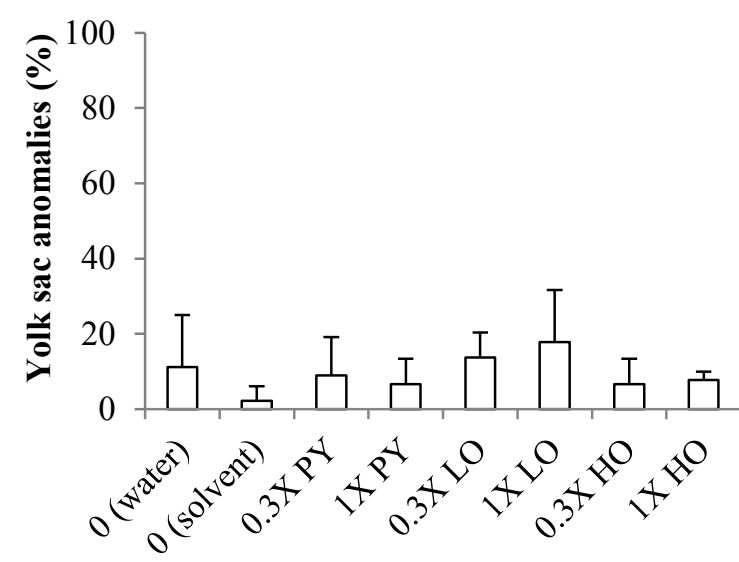

D

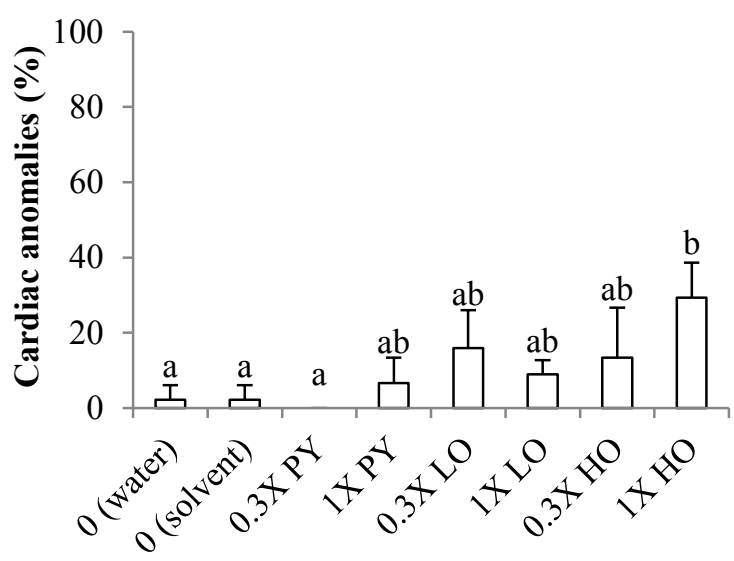

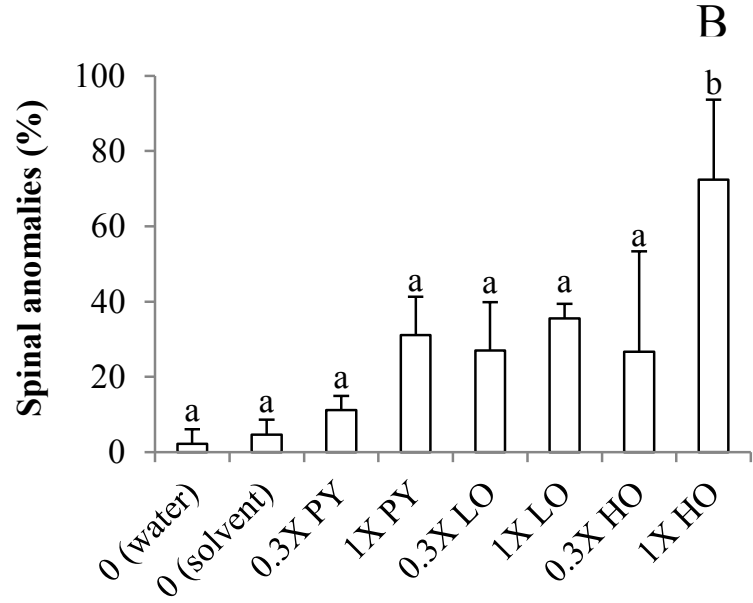

E

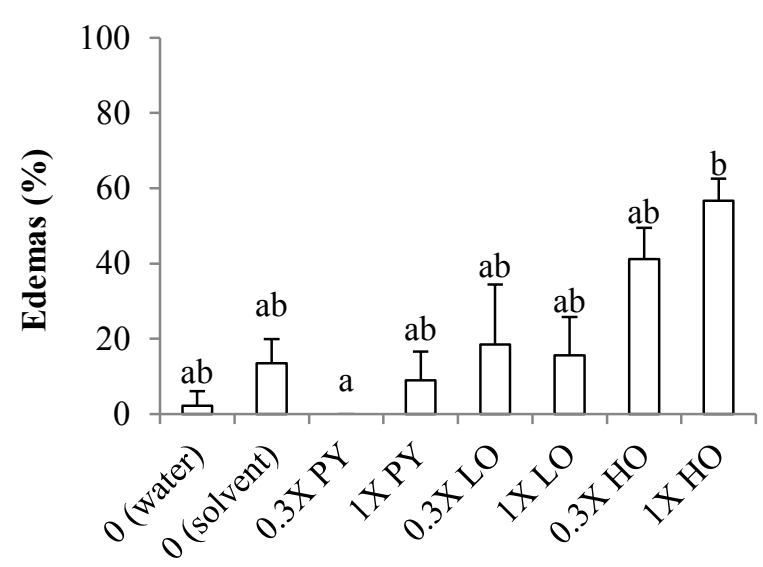

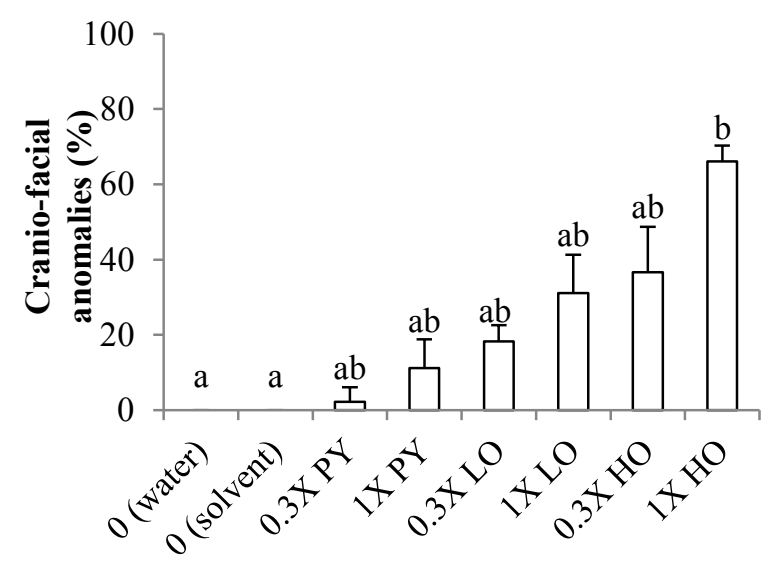

F

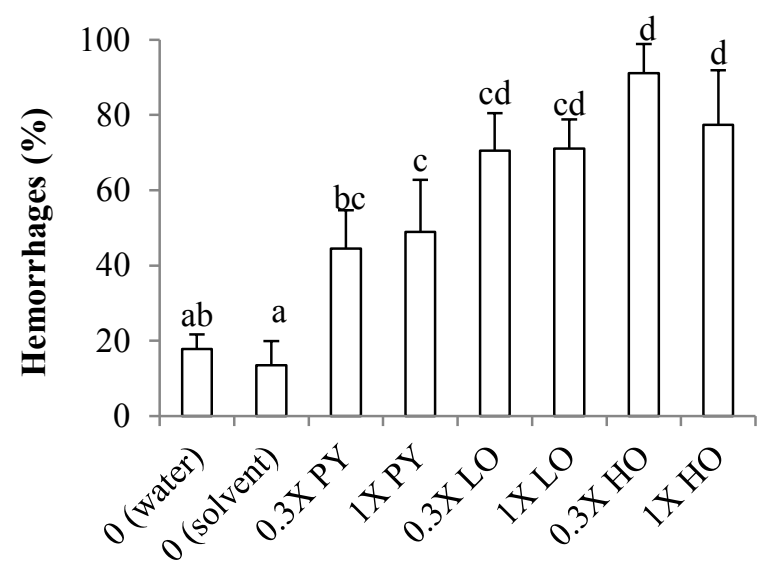




\section{Figure 3}

A
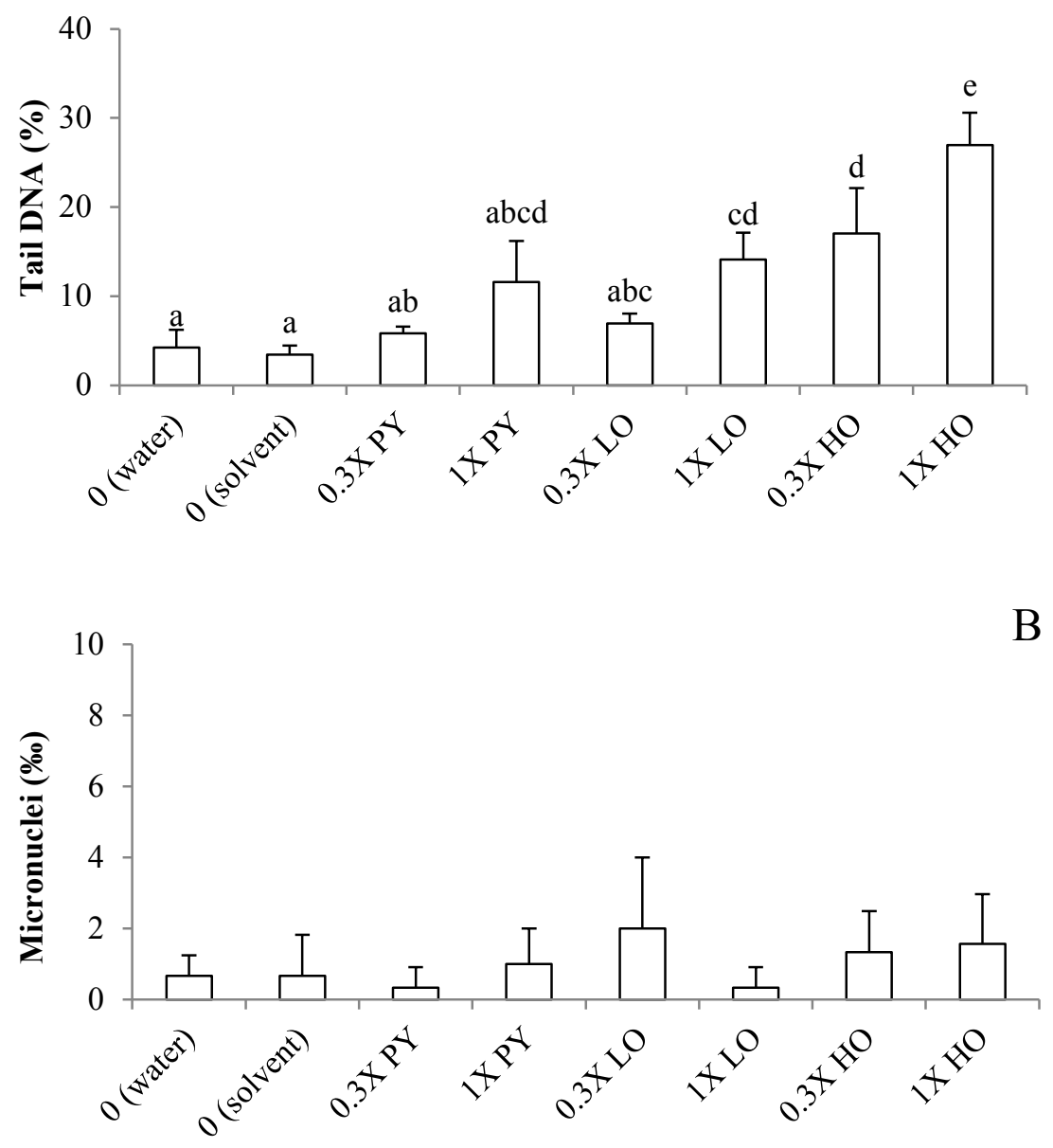


\section{Figure 4}
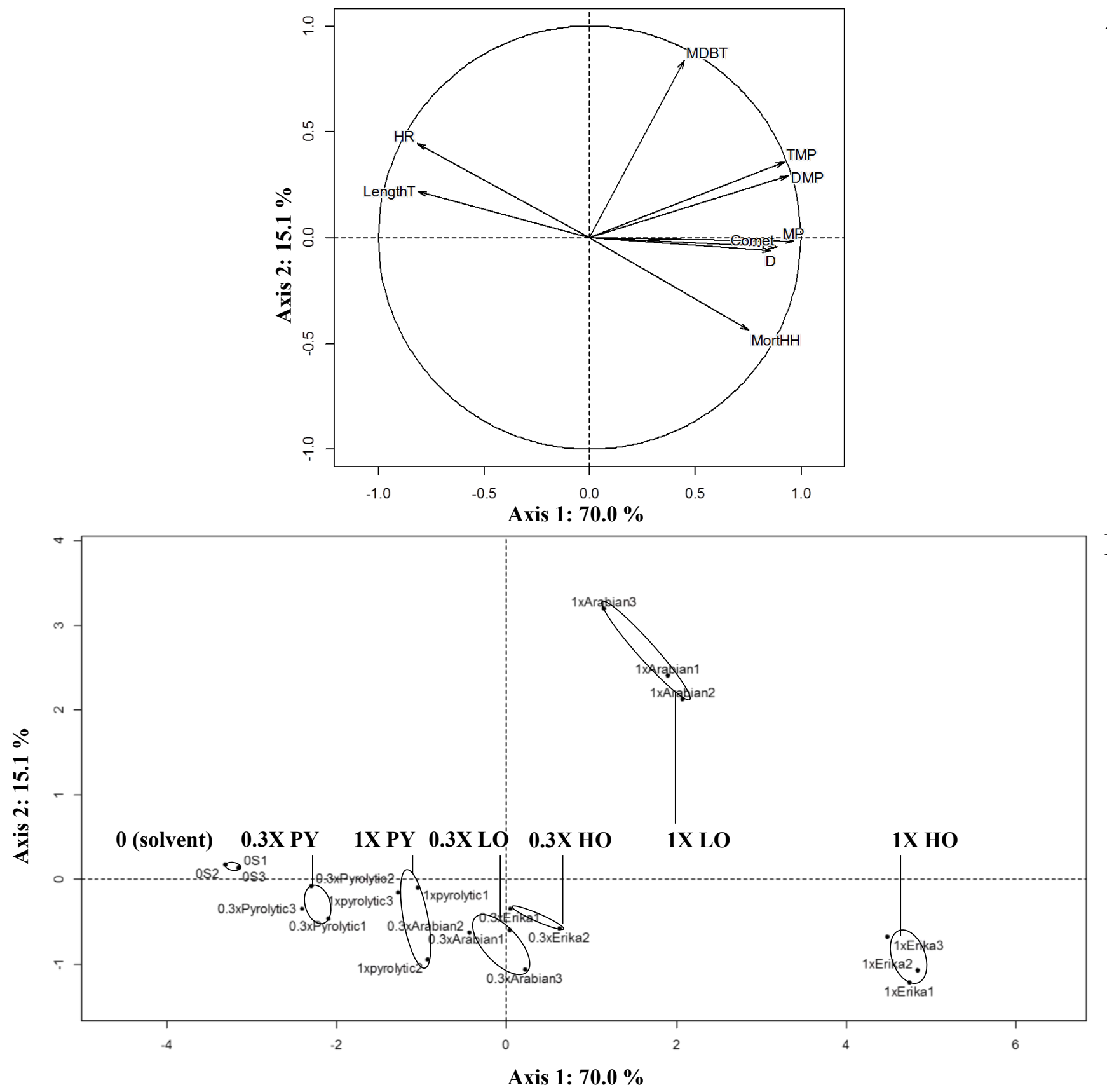


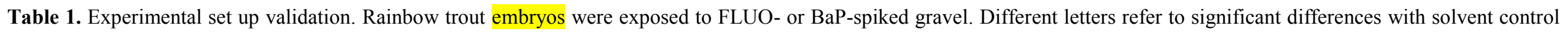
(Mean $\pm \mathrm{SD}, \mathrm{N}=3$, Anova, $\mathrm{p}<0.05$ ).

\begin{tabular}{|c|c|c|c|}
\hline & 0 (Solvent) & BaP $3 \mu \mathrm{g} \mathrm{g}^{-1} \mathrm{dw}$ & FLUO $3 \mu \mathrm{g} \mathrm{g}^{-1} \mathrm{dw}$ \\
\hline PAH concentration $\left(\mathrm{ng} \mathrm{g}^{-1} \mathrm{dw}\right)$ (spiking efficiency $\%$ ) & $\mathrm{ND}^{1}$ & $1110(37)$ & $2657(88)$ \\
\hline Embryonic mortality (\%) & $2.0 \pm 2.8$ & $2.7 \pm 2.3$ & $6.7 \pm 2.3$ \\
\hline Larval mortality (\%) & $2.2 \pm 3.1$ & $0.0 \pm 0.0$ & $0.0 \pm 0.0$ \\
\hline Half-hatched embryos mortality (\%) & $0.0 \pm 0.0$ & $2.7 \pm 4.6$ & $0.0 \pm 0.0$ \\
\hline Time to hatch (DD) & $359.2 \pm 9.4$ & $362.7 \pm 4.2$ & $360.4 \pm 4.7$ \\
\hline Hatching rate $(\%)$ & $94.0 \pm 2.8$ & $86.7 \pm 2.3$ & $92.0 \pm 10.6$ \\
\hline Larvae head length (mm) & $12.6 \pm 0.6$ & $12.4 \pm 0.3$ & $12.2 \pm 0.1$ \\
\hline Larvae total length (mm) & $2.70 \pm 0.13$ & $2.62 \pm 0.06$ & $2.62 \pm 0.06$ \\
\hline Larval abnormalities (\%) & $10.0 \pm 4.7^{\mathrm{a}}$ & $64.4 \pm 13.9^{b}$ & $56.7 \pm 8.8^{b}$ \\
\hline Yolk-sac & $0.0 \pm 0.0$ & $8.9 \pm 10.2$ & $5.0 \pm 4.4$ \\
\hline Spinal & $0.0 \pm 0.0^{\mathrm{a}}$ & $17.8 \pm 3.8^{b}$ & $16.7 \pm 3.3^{b}$ \\
\hline Craniofacial & $0.0 \pm 0.0$ & $4.4 \pm 3.8$ & $16.1 \pm 9.5$ \\
\hline Cardiac & $0.0 \pm 0.0$ & $2.2 \pm 3.8$ & $2.2 \pm 3.8$ \\
\hline Edema & $10.0 \pm 4.7^{\mathrm{a}}$ & $35.6 \pm 7.7^{b}$ & $38.3 \pm 10.4^{b}$ \\
\hline Hemorrhages & $0.0 \pm 0.0$ & $20.0 \pm 11.5$ & $25.0 \pm 14.4$ \\
\hline
\end{tabular}

Non Detected 
Table 2. Measured PAH concentrations in gravels spiked with three different PAH fractions LO, HO or PY (ng $\left.\mathrm{g}^{-1} \mathrm{dw}\right)$.

\begin{tabular}{|c|c|c|c|c|c|c|c|c|c|}
\hline & & & Solvent & PY & & LO & & HO & \\
\hline Compound & $\mathbf{N}$ cycles & $\mathbf{L Q}^{1}$ & $\mathbf{0}$ & $0.3 \mathrm{X}$ & $1 \mathrm{X}$ & $0.3 \mathrm{X}$ & $1 \mathrm{X}$ & $0.3 \mathrm{X}$ & $1 \mathrm{X}$ \\
\hline Naphthalene* & 2 & 1 & $<\mathrm{LQ}$ & $<\mathrm{LQ}$ & 9 & $<\mathrm{LQ}$ & 91 & 2 & 34 \\
\hline Acenaphthylene* & 3 & 1 & $<\mathrm{LQ}$ & 7 & 27 & $<\mathrm{LQ}$ & 165 & $<\mathrm{LQ}$ & 5 \\
\hline Acenaphthene* & 3 & 1 & $<\mathrm{LQ}$ & 2 & 12 & $<\mathrm{LQ}$ & 147 & 8 & 46 \\
\hline Fluorene* & 3 & 5 & $<\mathrm{LQ}$ & 7 & 38 & 23 & 141 & 23 & 96 \\
\hline Dibenzo $[b d]$ thiophene & 3 & 5 & $<\mathrm{LQ}$ & 6 & 30 & 163 & 795 & 47 & 144 \\
\hline Phenanthrene* & 3 & 10 & $<\mathrm{LQ}$ & 58 & 256 & 65 & 366 & 121 & 444 \\
\hline Anthracene* & 3 & 10 & $<\mathrm{LQ}$ & 21 & 118 & $<\mathrm{LQ}$ & 32 & 19 & 68 \\
\hline Fluoranthene* & 4 & 5 & $<\mathrm{LQ}$ & 140 & 490 & $<\mathrm{LQ}$ & 14 & 22 & 62 \\
\hline Pyrene* & 4 & 5 & $<\mathrm{LQ}$ & 115 & 399 & $<\mathrm{LQ}$ & 12 & 67 & 256 \\
\hline Benzo $[a]$ anthracene* & 4 & 10 & $<\mathrm{LQ}$ & 79 & 234 & $<\mathrm{LQ}$ & $<\mathrm{LQ}$ & 45 & 182 \\
\hline Triphenylene + Chrysene* & 4 & 10 & $<\mathrm{LQ}$ & 101 & 315 & 20 & 89 & 101 & 376 \\
\hline $\operatorname{Benzo}[b]$ naphto $[2,1-d]$ thiophene & 4 & 10 & $<\mathrm{LQ}$ & $<\mathrm{LQ}$ & 65 & 36 & 168 & 49 & 244 \\
\hline Benzo[b+k+j]fluoranthene* & 5 & 10 & $<\mathrm{LQ}$ & 205 & 626 & $<\mathrm{LQ}$ & 25 & 32 & 102 \\
\hline Benzo $[e]$ pyrene & 5 & 5 & $<\mathrm{LQ}$ & 76 & 235 & 9 & 36 & 44 & 160 \\
\hline Benzo[a]pyrene* & 5 & 10 & $<\mathrm{LQ}$ & 74 & 244 & $<\mathrm{LQ}$ & $<\mathrm{LQ}$ & 32 & 120 \\
\hline Perylene & 5 & 10 & $<\mathrm{LQ}$ & 28 & 89 & $<\mathrm{LQ}$ & $<\mathrm{LQ}$ & 13 & 58 \\
\hline $\begin{array}{l}\text { Indeno[1,2,3-cd] pyrene* } \\
\text { Dibenzo[ah] anthracene* }\end{array}$ & 6 & 10 & $<\mathrm{LQ}$ & 103 & 328 & $<\mathrm{LQ}$ & $<\mathrm{LQ}$ & $<\mathrm{LQ}$ & 38 \\
\hline +Dibenzo[ac]anthracene & 5 & 5 & $<\mathrm{LQ}$ & 39 & 125 & $<\mathrm{LQ}$ & $<\mathrm{LQ}$ & 15 & 25 \\
\hline Benzo $[$ ghi $]$ perylene* & 6 & 10 & $<\mathrm{LQ}$ & 86 & 281 & $<\mathrm{LQ}$ & $<\mathrm{LQ}$ & 48 & 187 \\
\hline 2-Methylnaphthalene & 2 & 1 & $<\mathrm{LQ}$ & $<\mathrm{LQ}$ & 15 & 29 & 524 & 29 & 239 \\
\hline 1-Methylnaphthalene & 2 & 1 & $<\mathrm{LQ}$ & $<\mathrm{LQ}$ & 4 & 37 & 621 & 19 & 172 \\
\hline 3-Methylphenanthrene & 3 & 10 & $<\mathrm{LQ}$ & 14 & 66 & 57 & 242 & 116 & 403 \\
\hline 2-Methylphenanthrene & 3 & 10 & $<\mathrm{LQ}$ & 14 & 108 & 69 & 308 & 183 & 643 \\
\hline $\begin{array}{l}\text { 2-Methylanthracene } \\
\text { 9-Methylphenanthrene + }\end{array}$ & 3 & 10 & $<\mathrm{LQ}$ & 23 & $<\mathrm{LQ}$ & $<\mathrm{LQ}$ & $<\mathrm{LQ}$ & 25 & 97 \\
\hline 2-Methylanthracene & 3 & 10 & $<\mathrm{LQ}$ & $<\mathrm{LQ}$ & 60 & 123 & 22 & 92 & 320 \\
\hline 1-Methylphenanthrene & 3 & 10 & $<\mathrm{LQ}$ & 11 & 61 & 65 & 283 & 89 & 317 \\
\hline 4-Methyldibenzothiophene & 3 & 2 & $<\mathrm{LQ}$ & 8 & 40 & 273 & 1182 & 73 & 209 \\
\hline 3+2-Methyldibenzothiophene & 3 & 2 & $<\mathrm{LQ}$ & $<\mathrm{LQ}$ & 22 & 251 & 1206 & 80 & 269 \\
\hline 1-Methyldibenzotiophene & 3 & 2 & $<\mathrm{LQ}$ & $<\mathrm{LQ}$ & 13 & 164 & 757 & 21 & 100 \\
\hline Dimethylnaphthalenes & 2 & 5 & $<\mathrm{LQ}$ & 10 & 100 & 442 & 4225 & 251 & 1228 \\
\hline Trimethylnaphthalene & 2 & 5 & $<\mathrm{LQ}$ & 17 & 76 & 859 & 6198 & 464 & 1533 \\
\hline Tetramethylnaphthalenes & 2 & 5 & $<\mathrm{LQ}$ & 14 & 81 & 557 & 4142 & 250 & 1053 \\
\hline Dimethylphenanthrenes & 3 & 10 & $<\mathrm{LQ}$ & 72 & 345 & 543 & 2198 & 753 & 2652 \\
\hline Trimethylphenanthrenes & 3 & 10 & $<\mathrm{LQ}$ & 57 & 281 & 522 & 2128 & 678 & 2274 \\
\hline Methylchrysenes & 4 & 10 & $<\mathrm{LQ}$ & 93 & 335 & 69 & 306 & 525 & 1964 \\
\hline$\Sigma$ US EPA priority PAHs* & & & $<\mathrm{LQ}$ & 1038 & 3503 & 108 & 1082 & 535 & 2040 \\
\hline Spiking efficiency (\%) & & & & 40 & 42 & 24 & 42 & 42 & 50 \\
\hline
\end{tabular}

* PAHs labelled as priority substances by the US Environmental Protection Agency

${ }^{1}$ Limite of quantification 


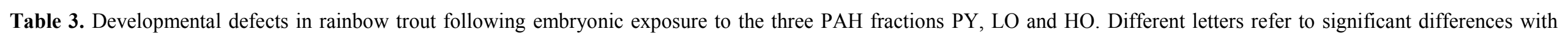
solvent control (Mean $\pm \mathrm{SD}, \mathrm{N}=3$, Anova / KW, $\mathrm{p}<0.05)$.

\begin{tabular}{|c|c|c|c|c|c|c|c|c|}
\hline & 0 (water) & O (solvent) & $0.3 X$ PY & 1X PY & $0.3 \times$ LO & $1 \times \mathrm{LO}$ & $0.3 \times$ HO & $1 \mathrm{X} \mathrm{HO}$ \\
\hline Embryonic mortality (\%) & $0.0 \pm 0.0$ & $0.0 \pm 0.0$ & $0.0 \pm 0.0$ & $1.3 \pm 2.3$ & $1.3 \pm 2.3$ & $1.3 \pm 2.3$ & $0.0 \pm 0.0$ & $13.3 \pm 8.3$ \\
\hline Larval mortality (\%) & $3.9 \pm 6.8$ & $1.7 \pm 2.9$ & $3.5 \pm 6.1$ & $8.7 \pm 5.5$ & $8.0 \pm 8.9$ & $6.3 \pm 10.8$ & $2.6 \pm 3.7$ & $25.1 \pm 31.2$ \\
\hline Half-hatched embryos (\%) & $1.3 \pm 2.3^{\mathrm{a}}$ & $0.0 \pm 0.0^{\mathrm{a}}$ & $2.7 \pm 2.3^{\mathrm{ab}}$ & $2.7 \pm 4.6^{\mathrm{ab}}$ & $10.7 \pm 2.3^{b c}$ & $4.0 \pm 4.0^{\mathrm{a}}$ & $4.0 \pm 0.0^{\mathrm{ab}}$ & $14.7 \pm 2.3^{\mathrm{c}}$ \\
\hline Hatching rate $(\%)$ & $98.7 \pm 2.3^{\mathrm{ab}}$ & $100.0 \pm 0.0^{\mathrm{a}}$ & $97.3 \pm 2.3^{\mathrm{ab}}$ & $94.7 \pm 6.1^{\mathrm{ab}}$ & $86.7 \pm 2.3^{\mathrm{ab}}$ & $94.7 \pm 4.6^{\mathrm{ab}}$ & $96.0 \pm 2.3^{\mathrm{ab}}$ & $72.0 \pm 6.9^{b}$ \\
\hline Time to hatch (DD) & $315.6 \pm 5.9$ & $318.9 \pm 6.5$ & $316.5 \pm 3.1$ & $311.1 \pm 5.5$ & $310.5 \pm 12.0$ & $316.7 \pm 6.2$ & $308.5 \pm 8.0$ & $308.0 \pm 6.8$ \\
\hline Abnormal larvae (\%) & $26.7 \pm 6.7^{\mathrm{a}}$ & $31.6 \pm 9.4^{\mathrm{a}}$ & $48.9 \pm 7.7^{\mathrm{ab}}$ & $68.9 \pm 10.2^{b c}$ & $81.7 \pm 10.4^{\mathrm{cd}}$ & $82.2 \pm 10.2^{\mathrm{cd}}$ & $95.6 \pm 3.8^{d}$ & $100.0 \pm 0.0^{d}$ \\
\hline
\end{tabular}

